\title{
Estimating the value, ownership structure and turnover rate for investible commercial real estate from transaction datasets
}

Article

Accepted Version

Creative Commons: Attribution-Noncommercial 4.0

Devaney, S. ORCID: https://orcid.org/0000-0002-1916-2558 and Scofield, D. (2021) Estimating the value, ownership structure and turnover rate for investible commercial real estate from transaction datasets. Journal of Property Investment \& Finance, 39 (4). pp. 336-382. ISSN 1463-578X doi: https://doi.org/10.1108/JPIF-05-2020-0052 Available at https://centaur.reading.ac.uk/93949/

It is advisable to refer to the publisher's version if you intend to cite from the work. See Guidance on citing.

To link to this article DOI: http://dx.doi.org/10.1108/JPIF-05-2020-0052

Publisher: Emerald Group Publishing Limited

All outputs in CentAUR are protected by Intellectual Property Rights law, including copyright law. Copyright and IPR is retained by the creators or other copyright holders. Terms and conditions for use of this material are defined in the End User Agreement. 


\section{CentAUR}

Central Archive at the University of Reading

Reading's research outputs online 


\section{Estimating the Value, Ownership Structure and Turnover Rate for Investible Commercial Real Estate from Transaction Datasets}

\section{Structured abstract}

Purpose: Commercial real estate (CRE) is a major investment asset. Yet detailed information on the value of investible CRE in different cities is lacking. We propose an innovative method to measure the value of investible CRE using transaction datasets.

Design/methodology/approach: We take transaction prices and index them to produce a time series of values for each asset. The sum of the values at each point represents the value of investible CRE at that date. Our method is applied to transaction data for New York, London and Toronto.

Findings: London had the highest proportions of institutional and foreign ownership, and its turnover was more resilient to the downturn in global CRE following the GFC. The results illustrate the potential of our method to shed light on the characteristics of investible CRE markets.

Originality: Our modification of the perpetual inventory technique is simple, novel and practical. We propose this approach given the absence of a building-by-building inventory of investible CRE in many markets.

Research limitations: We use data from Real Capital Analytics (RCA). This provides good coverage of transactions for investible CRE in the cities that we examine, but data from other sources might lead to different estimates.

Practical implications: Measuring the value and turnover of investible CRE is important for portfolio strategies that account for the size and liquidity of investment markets. Knowledge of these features, and of ownership patterns, provides a better understanding of market operation.

Keywords: Market size; Ownership; Stock; Transactions; Turnover

Paper classification: Research paper 


\section{Estimating the Value, Ownership Structure and Turnover Rate for Investible Commercial Real Estate from Transaction Datasets}

\section{Introduction}

Commercial real estate (CRE) is a key factor of production in many industries and a major investment asset. As such, it makes an important contribution to the economy and is a significant component of national wealth. Yet detailed information on the value of CRE of different types in different locations is lacking. Knowledge of the value of CRE is especially important in the context of portfolio allocation - both to private real estate as an asset class and to specific sectors or regions (Mahoney et al., 2000; Florance et al., 2010). However, only certain types of CRE are typically considered investible by most professional investors (Key and Law, 2005), with traditional targets for investment capital being retail premises, offices and light industrial/warehouse properties as well as multifamily residential assets in some nations. This has stimulated research interest in both the value of the total non-residential real estate stock and the value of the investible stock, the latter being the focus of this paper.

The scale of investible real estate markets, together with the types of investors holding assets in those markets, is likely to have implications for liquidity and market operation (Baum and Lizieri, 1999; Devaney et al., 2017). Liquidity is difficult to capture using a single measure, as it relates to the cost, speed and impact of trading activity, but the amount of trading should reflect the ease of trading and so signal those markets and periods where liquidity is greater. The cash volume of trading is commonly noted in CRE market reports, yet cash volumes are influenced not only by market activity but also by trends in prices. For this reason, Devaney et al. (2017) advocate analysis of turnover rates since these scale transaction volumes to market size, but, consequently, this requires robust estimates of the value of CRE markets to be made (IPF, 2004). 
The value and turnover of CRE markets will reflect economic factors and institutional attributes. Larger and more active real estate markets are likely to attract more professional investment, including crossborder investment, that, in turn, may have positive effects on activity, transparency and overall value. Devaney et al. (2017) show a positive relationship between institutional investment flows and market size for US office markets. However, flows to secure entry to (or exit from) markets do not indicate the longer-term effects of changes in ownership. Lizieri and Mekic (2018) contend that change in the nature of ownership might lead to reduced activity if investors entering a market have different horizons and objectives to those that are divesting of stock. Hence, there is a strong case for measuring both activity and ownership within investible CRE markets to understand the impact of these factors on performance and liquidity, and the potential implications for portfolio strategies.

Despite this, estimates for the value of CRE stock by type and location are not readily available for most real estate investment markets. In the US, many researchers have commented on this. Thirty years ago, Fisher and Webb (1992) noted the lack of robust data regarding the value of CRE, with estimates for the US in the late 1980 s and early 1990 s ranging from $\$ 800$ billion to $\$ 5$ trillion (see also Miles, 1990). More recently, Silver and Graff (2014) have observed that determining the total value of different types of CRE across US markets is still a vexed issue. We argue that developing better, more systematic methods for tracking the value of CRE over time is an important research area where more attention is long overdue. This includes methods that lead to the development of new datasets and methods that exploit existing data sources to their maximum potential.

In this context, we propose a simple, yet effective, method for constructing estimates of the value and turnover of the investible CRE stock in different locations. This method involves building up a profile of the stock from records of assets that have transacted and it is proposed in the absence of a buildingby-building inventory in many metro areas. No single source of transaction information offers perfect coverage, but we apply our method to data from Real Capital Analytics (RCA) for New York, London 
and Toronto, three prominent CRE markets located within major financial centers. Although there has been prior research on market size and ownership for London CRE, reviewed below, we include this city in our analysis to benchmark our results against previous studies. Given a sufficiently large dataset of transactions in terms of time period and coverage, our approach should be effective in estimating the value of investible CRE.

The next section of the paper discusses previous attempts to quantify the value and turnover of CRE in the US and elsewhere. The following section then sets out our method and discusses the transaction data that we use to illustrate our approach. The fourth section discusses the results for our sample of CRE markets and a final section then concludes.

\section{Literature review}

The approach taken and data used for estimating the value of CRE markets depends in part on whether it is the total stock or investible stock that is of interest. Key and Law (2005) provide detailed discussion of these different concepts. They define the universe of CRE as those properties held by either owneroccupiers or investors, across both the public and private sectors. They further define two subsets of assets: invested, those properties currently held as investments; and investible, which includes those properties that have potential to be invested given their "transferability of use... lot size, and building quality" (p13) [1]. The value of investible CRE will be smaller than that of total CRE as captured within national accounts (as this includes non-investible infrastructure and social assets, plus other buildings whose attributes are unattractive to investors). Yet the pool of investible real estate is not fixed. The CRE investment market has expanded over time as owner-occupiers have divested of properties and as investors have financed and purchased assets in emerging sectors (e.g. student housing). 
Studies that have estimated CRE market value have also worked at different scales (global, national and local), although most studies of which we are aware have focused on national level estimates of either the total or investible CRE stock. Some authors have extrapolated national CRE values from known values for a small number of locations, while others have employed a top-down approach, e.g. estimating the approximate value of CRE in different nations using a sliding ratio of GDP (higher for developed economies, lower for less developed economies). Meanwhile, other studies have applied perpetual inventory methods to building permit or construction data, depreciated over time, in order to derive CRE stock values (e.g. Young and Musgrave, 1980; Rogers and Blake, 2013). Since the robust estimation of stock forms a basis for estimating market turnover and ownership, we focus on research that has attempted to estimate CRE market value.

Beginning with the United States, and working chronologically, Miles (1990) estimates value of the CRE stock in the US at approximately $\$ 2$ trillion (1988). The IREM Foundation and Arthur Anderson (as cited in Fisher and Webb, 1992) strapped together a number of data sources to arrive at a value of $\$ 3.78$ trillion for US CRE. The Bureau of Economic Analysis estimated total business property value in the US at $\$ 4.7$ trillion (as cited in Hartzell et al., 1994). DiPasquale and Wheaton (1992) analyzed US Census Data and approximated the value of the CRE stock at approximately $\$ 2.7$ trillion (1990), noting that $56 \%$ of the nations' wealth was held in real estate (p.184).

Miles et al. (1991) estimated the value of commercial and industrial real estate in the US to be \$2.7 trillion and the size of the CRE stock to be 26.7 billion sq. $\mathrm{ft}$. They also estimated the value of residential real estate at $\$ 6.1$ trillion. To make these estimates, they modelled the relationship between countylevel property tax assessment data and demographic variables for a small sample of urban areas, and then extrapolated the relationship to non-sample areas to estimate aggregate value per property type at the state level. The authors provide several caveats for their findings. For instance, many states / 
counties did not track square footage and some states did not disclose CRE tax data at the time, e.g. California.

Hartzell et al. (1994) used county-level data on assessed property values coupled with demographic and economic data to determine values by property type (residential, office, retail and industrial) and geographical area across the US. The authors multiplied the assessed values by the ratio of assessedto-market value (as determined by sales data) to arrive at the value of each property type in each area in their sample of 67 counties. They then regressed these values on to economic and demographic variables for each area to extrapolate the value of the stock for the United States as a whole and for the 44 largest MSAs. Although the explanatory power of their model was not uniformly strong for all types and locations, the authors estimated the value of the US CRE market to be $\$ 2.43$ trillion as at 1989 , with the residential real estate market valued at $\$ 8.7$ trillion [2]. As in the case of Miles et al. (1991), the sample of counties used in the estimations had some notable omissions; for instance, there were no counties from the New York and Chicago MSAs or from California.

Miles et al. (1994) estimate market values for public and private real estate investment markets, both US and global. They identified difficulties inherent to estimating the aggregate value of private real estate investment, including issues around double and triple counting of assets. The authors parse the private from the public, before defining the aggregate values of the investible private market. Using property tax records and NCREIF data to adjust for changes in market values and capital expenditure, they arrived at estimates for private CRE investment in the US at $\$ 3.98$ trillion, including multifamily assets and hotels. This figure was revised in Miles and Tolleson (1997) to \$3.8 trillion.

Malpezzi et al. (2001) employed a modified perpetual inventory method using Census of Governments (COG) data as a baseline for stock estimates per MSA. The COG was conducted at five-year intervals, ending in 1982. Thus, 1982 was the start date for the method used by Malpezzi et al. The authors 
estimated the values of single-family residential and of income producing real estate in each of 242 MSAs. They did this by taking the prior year's value, adjusting it by the rate of inflation, subtracting an allowance for depreciation and then adding new investment as indicated by the BEA building permits data. Such estimates were applied in Mahoney et al. (2000) and Malpezzi and Shilling (2000) to test whether institutional investors hold assets in higher quality locations than REITs. This was done by comparing the estimates of stock to portfolio holdings of these investor types as tracked by the NCREIF and Fidelity REIT databases.

In a series of studies, beginning with Liang and McIntosh (1999), researchers at Pramerica estimated national CRE market sizes as a function of output and wealth. In this series, Fiorilla et al. (2012) discuss how CRE stock values are extrapolated based on national GDP and the level of economic development. They estimated CRE value at 45\% of GDP in developed countries, while the proportion for developing countries (defined as GDP per capita below USD $\$ 26,115$ at 2011) diminished as the GDP per capita dropped. The authors valued US CRE stock at $\$ 6.8$ trillion for 2011. More recently, researchers at MSCI have produced regular estimates of national CRE market sizes, placing the US CRE investment market at \$3.1 trillion as at 2018 (Teuben and Bothra, 2019). The estimate is much smaller as MSCl explicitly concentrate on the value of professionally managed real estate investments and exclude both owneroccupied and sub-investment grade assets, highlighting how definitions matter in these exercises as well as measurement methods.

Florance et al. (2010) estimate the size and value of US CRE stock using US Census data and transaction data from Co-Star. The transaction data was used to determine price per square foot by property type and metro area, though, for some areas, income and cap rate information was used to estimate prices. The authors determined the size of stock by property type and its approximate value as a percentage of replacement cost. They calculated the total square footage of CRE at 100 billion square feet, or 328 square feet per person, and they estimated that core CRE stock was worth $\$ 9.5$ trillion in the US (2009; 
excl. owner-occupied). In principle, their study was one of the most complete examinations of the US CRE stock, but value estimates are only reported for the United States as a whole. MSA-level reporting related to the total square footage of stock in the main CRE types of office, industrial, retail and flex space.

There have been several examinations of the value of CRE in the United Kingdom. For example, Rogers and Blake (2013) applied the perpetual inventory method to construction data, estimating the value of the UK CRE stock to be $f 661 \mathrm{bn}$ for 2008. A comprehensive review of the CRE stock by property type and region, including total value and value held by different investor groups, was undertaken by Key and Law (2005). The basis for their figures on total value were assessments of rental values conducted for taxation purposes. These were converted to capital values using capitalization rates for investment assets adjusted for differences in quality between investment-grade and typical CRE stock. As at 2003, the authors estimated the value of all CRE in the UK at $f 611$ billion, with the London region at $f 163 \mathrm{bn}$, or $27 \%$ of that total. Their study has been subject to several updates, notably by Mitchell (2014) and most recently by Key et al. (2019), though the basic methods and sources are largely unchanged [3].

Many of the studies discussed above have little to say in regards to market turnover. This is because the data and methods used to gauge CRE market value are not necessarily compatible with available information on transaction volumes. For example, studies that have applied the perpetual inventory method have used data on construction activity that might incorporate investible and non-investible parts of the CRE market. There are also studies that have measured turnover relative to the portfolio holdings of specific investor groups. For instance, the detailed analysis of UK transaction activity within IPF (2004) was based largely on the IPD (now MSCI) dataset of institutional investors. IPF acknowledge that the results might be skewed by the strategies and activities of this particular group, which might explain some of the unusual results at segment level such as the low turnover rate for Central London offices. 
In the absence of published estimates for the value of the office stock in different cities, Devaney et al. (2017) and Devaney et al. (2019) take estimates of floorspace from real estate advisory firms and convert these into capital values using published market indicators for rents and capitalisation rates in those locations. This produced denominators against which office transaction volumes for the cities in their sample could be scaled. However, values produced this way could be prone to measurement error and result in unusual figures for particular markets. While the estimates for US office markets in Devaney et al. (2017) appear broadly plausible, the estimates of Devaney et al. (2019) for international office markets included average annual turnover rates of over $20 \%$ of stock for Chicago, San Francisco and Seoul, which seem implausible.

It is also possible to infer turnover rates from information on asset holding periods. For instance, if the average holding period is ten years, it implies that ten percent of stock will be traded each year (where the proportion traded is the inverse of the hold period). Collett et al. (2003) studied average investor holding periods for the UK, while Fisher and Young (2000) have done so for the US. These studies were based on CRE owned by institutional investors. Both studies found that holding periods reduced over the time frames they analysed, suggesting that turnover rose, and found variations by market state and property type. Once again, these results might only reflect changing preferences and investment decisions of institutional investors - not market activity in general.

All estimates of either the total value or the turnover rate of real estate are subject to uncertainties. In relation to value, top-down methods that estimate national CRE values based on relationships to GDP or other variables offer only very broad figures. Econometric modelling of the stock for samples of areas might be used as a basis for extrapolation, but this presents issues where samples are small or unrepresentative. A census-based approach relies on a need for a census of values, such as taxation, and this might not be performed regularly or frequently. Finally, perpetual inventory exercises require 
adequate data on new construction and are sensitive to the assumptions adopted. In this context, our method is advocated for its ease of application, its ability to disaggregate by property types and areas, and the additional insights it can provide into the ownership of investible CRE in different markets.

\section{Method and data}

The method adopted in this paper is related to the traditional perpetual inventory method in that we use data on flows to infer the value of the real estate stock. The typical application of the perpetual inventory method is to cumulate capital invested in the production of new assets. So the value of the capital stock at time $t$ is simply the sum of all stock produced over $t-\tau$, where $\tau$ is the first period where production of new assets is measured. However, in order to prevent older vintages of assets remaining in the stock indefinitely, the approach is augmented using assumptions about asset lives and patterns of depreciation. In other words, the values of assets built in earlier periods are reduced by an assumed depreciation rate, $\delta$, and, eventually, removed from the calculation altogether at an assumed age of retirement.

The perpetual inventory method as described above is used to estimate the stock of fixed capital in national accounts. It requires data on flows of investment into new buildings, which can be recorded in time series tracking building permits, construction orders or completions. Some of these series may not account for the value of the land underlying the building (Mitchell, 2014). Furthermore, the time period required to ensure credible estimates of stock can be long unless a census of stock is available at a specific date. Yet a census of values is often not available for many CRE markets. It can also be difficult to match the results of census exercises conducted for administrative areas to the submarket areas or property types of relevance to professional real estate investors. 
Flows of capital also arise from the trading of assets in the real estate market. Data on transactions is available from commercial organisations and from government records in some nations that register transactions and property ownership. Transaction data seems to have been rarely used for estimating the value of CRE. However, such data were used by Scofield and Devaney (2017) in their study of the UK CRE market. They compared characteristics of buildings that traded to the characteristics of those that did not, where the stock of unsold buildings in any year was formed using the records of assets that traded in other years. The authors did not provide much detail on how the unsold set was formed each time and did not report how total stock changed through time. Meanwhile, Mitchell (2014: 23) estimated the value of Central London CRE at 2013 using the RCA dataset of transactions. He did not explain his approach in detail either, but it is based on summing purchases recorded by RCA from the beginning of their coverage up to that particular point in time.

We adopt a similar approach here, but we use details of prices, buyers and sellers to estimate values and ownership of CRE both forwards and backwards through time. We set out in detail how estimates of the value of CRE for a given market might be identified from transaction records compiled for that market. We apply our approach to data for the metro areas of New York, London and Toronto. Records of CRE transactions in the three cities were obtained from RCA, an established provider of transaction data for global real estate markets. According to Newell et al. (2013: 6), RCA is "the largest and most comprehensive commercial property transactions database available globally". Their coverage is cited to be most, if not all, CRE transactions in the US over $\$ 2.5 \mathrm{~m}$ (see Devaney and Scofield, 2017; Freybote and Seagraves, 2017), and CRE sales over $\$ 10 \mathrm{~m}$ at a global level (see Newell et al., 2013; Chegut et al., 2015) [4].

The data related to industrial, office, retail, hotel and apartment building sales, and spanned 2001q1 to $2018 q 1$ for New York and London, and 2007q1 to 2018q1 for Toronto [5]. Portfolio deals were also included and were used in the exercise if each of the constituent assets in the sale could be identified. 
Otherwise, the record was discarded. The number and value of transactions in our data for each metro area is reported in Table I. New York has over four times as many transactions as London, but the total value of these is only c. $40 \%$ greater, whereas ratios of the number and value of transactions for New York compared to Toronto are more consistent. Average transaction price is similar for New York and Toronto, and lower than the $\$ 64.6 \mathrm{~m}$ average for London. The London dataset contains fewer sales of apartment blocks, as such buildings were historically not regarded as investible assets by professional investors in the UK. The London sample also appears more weighted towards the central areas of the city than in the case of New York or Toronto. This limitation will be borne in mind when interpreting the results.

\section{INSERT TABLE I HERE}

Table I also summarises price trends for each metro area based on the RCA Commercial Property Price Index (CPPI) relating to all property types. The comparison begins at end-2006 since the Toronto CPPI only starts from this date. New York had the strongest price growth since end-2006, while the slowest growth was in London. Table I and Figure 1 show that, of the three cities, London had the fastest and largest fall in CRE prices in response to the onset of the GFC. London also had the highest variability in quarterly price changes over this period. Whether the empirical analysis below reveals corresponding differences in ownership and trading activity will therefore be of interest.

\section{INSERT FIGURE 1 HERE}

Information on each transaction in our dataset consists of address, price, date of transaction, date of construction, and the type and size of property. It also includes details of the buyer and seller involved, including their type and nationality. RCA classifies buyers and sellers into four types of organisation: institutional, private, public and user/other. The institutional group includes insurance companies and 
pension funds, as well as pooled vehicles and separate accounts managed by investment management companies. 'Public' comprises listed REITs and REOCs, and 'private' includes nonlisted real estate firms and individuals. Finally, the user/other group includes properties bought and sold by non-real estate companies, charities, and national, state/provincial and local government bodies. The presence of this user/other group is important as it means that this dataset includes investible real estate assets that have not always been held within investment portfolios.

For nationality of buyer and seller, countries are attributed by RCA based on head office domicile. Yet international investors, particularly global investment management firms, can have many local offices and source capital from many locations when making investments (see McAllister and Nanda, 2015; Devaney and Scofield, 2017). Nonetheless, we use RCA descriptions of nationality to classify investors as domestic, foreign or unknown. Another issue is where there are multiple owners with different nationalities as in the case of joint ventures. Here, we split ownership between domestic, foreign and unknown in equal proportion based on the occurrence of each nationality type in the transaction. So, for example, in a purchase by a joint venture with one foreign and one domestic partner, the value of the transaction is split 50:50 as an approximation in the absence of information about the size of the constituent stakes.

The approach to creating estimates of the investible stock then proceeded as follows. First, for every building observed in the dataset, we identified if it was sold once or more than once. For properties that sold only once, we attribute ownership to the seller for all quarters prior to the quarter of sale and to the buyer for the quarter of sale and all subsequent quarters. This attribution is subject to a check regarding the year in which an asset was built, so that ownership is only attributed (and estimates of value made) for the quarters where a building physically existed. This point highlights that any changes to the value of the stock through time will, therefore, reflect both changes in prices and additions made through new construction. However, a limitation of the estimates here is that we 
do not observe when older buildings were withdrawn from the stock, which will create some upward bias to the estimates as the period progresses.

The procedure is more complicated for buildings that sold multiple times. In regard to the first sale of the asset, we attribute ownership to the seller for all quarters prior to sale, subject again to checking that the building physically existed in each of the quarters. We then attribute ownership to the buyer starting in the quarter of sale and ending in the quarter before a second sale, after which ownership is attributed to the new buyer. The process is then repeated as many times as is necessary, with the last recorded buyer then used as the owner for all remaining quarters in the period. So, for instance, if a property in New York was sold in 2006 and 2010, the 2006 record is used to identify ownership from 2001 to 2010, and the 2010 transaction record is used from 2010 through to 2018q1. The type and nationality of the identified owner at each point in time is then used to calculate what fraction of investible stock in a market or submarket is owned, say, by financial institutions or by foreign investors relative to other groups.

Having established a record of ownership for each asset over time, the next step is to estimate capital value at each point in time. This is achieved by indexing each recorded transaction price from the date of sale using the relevant RCA CPPI for the submarket and property type concerned. The RCA indexes are quarterly and they are based on the repeat sales method, as discussed by Geltner and Pollakowski (2007) and Silver and Graf (2014) [6]. A set of RCA CPPIs existed for New York and for London, but only a single, metro-level series was available for Toronto at the time of writing. Prices for each asset were indexed forwards through time until either a new transaction was observed (in which case the new price was then used) or the end of the study period was reached. Meanwhile, the first observed price for any building was indexed back to the start of the period, subject to a check on its construction date in line with the approach to tracing ownership set out above. 
Competing indexes are available for some of the metros studied, but an advantage of the RCA indexes is that they are transaction-based and not susceptible to some of the issues documented for appraisal indexes around timeliness of recording market movements (Geltner et al. 2003). They also estimate price appreciation unadjusted for capital expenditures, in contrast to capital return indexes published by performance measurement services (Young, 2005). Moreover, the RCA indexes reflect transactions that involved a broad sample of investors rather than just institutional investors or any other specific group. The accuracy of capital value estimates obtained by an indexing procedure of this nature might be questioned, yet its purpose is not to obtain accurate estimates of individual property values but reasonable aggregate estimates for metro areas. So, although the approach will generate errors at the individual property level, these should be diversified at the aggregate level.

The sum in each period of the capital values estimated for each asset provides a time series for either the value of the total investible stock in each metro or of the value for individual areas and property types. The figures can then be used as the denominator for calculating turnover rates. As noted earlier, turnover rates are arguably a better measure of market activity than volume traded, as cash volumes can change as prices rise and fall, even if trading activity is relatively stable. So we proceed to measure turnover rates in each period as follows:

$$
\text { Turnover rate }=\frac{\text { Volume traded }}{\left(\text { Value }_{t}+\text { Value }_{t-1}\right) \div 2}
$$

Where Value $\mathrm{t}_{\mathrm{t}-1}$ and Value $\mathrm{t}$ are estimates of the total value of the investible CRE stock for the market or segment at the start and end of the measurement period, respectively. The turnover rate indicates the proportion of stock by value that sold in a given period, with the average value of investible stock in that period used as the denominator. 


\section{Results}

Table II shows the estimates for the value of the investible stock that result from applying our method to the data for the three metro areas. While estimates are available for each year end covered by our datasets, the table focuses on four time points. End-2001 is the earliest possible year end for the New York and London datasets. End-2006 provides a date prior to the onset of the GFC and is the earliest year end for the Toronto dataset. End-2011 provides a view in the aftermath of the GFC. Finally, end2017 is the last year end covered by our dataset. The table reports figures in both local and US dollar terms. The latter are reported to facilitate comparison across different markets, but these estimates are subject to the prevailing exchange rates at each date in question.

INSERT TABLE II HERE

The growth in the value of the investible CRE stock through time in part reflects the price trends shown earlier in Table I, though with variations by property type taken into account. However, the recorded growth also reflects the development and sale of new stock in this period. For example, in New York, the total value of the estimated investible stock rose by $273 \%$ from end-2001 to end-2017. $232 \%$ was accounted for by price appreciation in the various market segments, while $42 \%$ was accounted for by new additions, an $85 / 15$ split. These two factors explain why the local currency-based values in all the cities between end-2006 and end-2011 do not fall as markedly as might be anticipated, since price falls for existing properties were offset by the addition of new buildings whose construction began in stronger market conditions.

Table II also shows figures for the apartment and office sectors. The office sector is shown as it is the most valuable property type based on the coverage of the available data. As there might be some bias 
towards central areas in the London data, the office sector is likely to be the most amenable to crosscity comparisons. New York and London appear to vie for the title of most valuable office market, with this partly dependent on the relative strength of Sterling and the US dollar over time, although London also experienced lower price growth (see Table I). This makes the disparity between the cities in terms of apartments more notable. Yet, results for apartments are consistent with a focus on the investible stock. While investment markets for multifamily assets in North America are long-established, flows of capital for the development and retention of apartment blocks by UK investors are far more recent; hence, both the small absolute value and rapid growth for this sector in London.

Some comparisons with earlier studies are possible though hindered by differences in time period and definition. Malpezzi et al. (2001) noted a value of $\$ 190 \mathrm{bn}$ for income producing property in New York MSA as at 1994, as high as our value estimate for end-2001, while Mahoney et al. (2000) reported a figure of $\$ 204 \mathrm{bn}$ as at 1998 . While these studies had the advantage of using a full census of stock as a baseline, their estimates covered all non-residential property types, including both investible and noninvestible assets, and the estimates could not be disaggregated into individual property types. Hence, some of the difference from our figures will reflect property types that are not considered investible stock and for which transactions will not appear in the RCA dataset.

Meanwhile, as noted earlier, Key and Law (2005) reported a value of $£ 163 \mathrm{bn}$ for London CRE at 2003, with $f 82 \mathrm{bn}$ relating to offices. These estimates were updated by Mitchell (2014), who reported a value of $£ 223 \mathrm{bn}$ as at 2013 , with $£ 114 \mathrm{bn}$ in offices. Our 2003 values are $£ 100 \mathrm{bn}$ for total CRE and $£ 69 \mathrm{bn}$ for the office sector, while our 2013 values are $£ 178 \mathrm{bn}$ and $£ 124 \mathrm{bn}$, respectively. Variations in the total CRE figures might be explained with reference to definitions and coverage, but differences in the office figures are more likely to reflect the methods and sources used. While we again acknowledge that the coverage of RCA is not perfect, we note that the alternative estimates by Key and Law and by Mitchell 
are subject to assumptions around the capitalization of rent-based tax assessments. When we isolate the office sector, there is greater consistency between our results and these earlier studies.

Table III presents results on the ownership of investible CRE in the three cities at the same time points used above. There are notable differences between the cities. In London, institutional investors hold a much greater proportion of the estimated investible stock by value than in the case of either Toronto or New York, amounting to more than half by value since the end of 2010. This does not simply reflect that offices have a greater share in the London data; the proportions are also higher for sectors not shown in this table. Only the Toronto office market has a comparable proportion of institutional investment to the levels shown in the London data. By contrast, private investors held the largest share by value in New York throughout this period, while they also held a significant share of investible CRE in Toronto. These differences are of interest in light of the possible positive association between institutional ownership and market activity posited earlier.

\section{INSERT TABLE III HERE}

For London and New York, the proportion of investible CRE owned by institutional investors has been relatively stable through time, but there appears to have been some displacement of publicly listed investors by private investors in London in this period. Meanwhile, there was growth in the share of CRE held by publicly listed investors for both New York and Toronto. In New York, this accompanied a fall in the proportion held by users and other non-investment organisations, while the picture is less clear in Toronto owing to a substantial fraction of unknown ownership (16\%) at the start of the period, reflecting cases where details of the seller were not captured in the transaction records. The increase in share of investible CRE held by publicly listed firms in Toronto post-GFC is particularly notable and reflects the considerable expansion of the Canadian REIT sector in this period. 
Table IV then presents results by property type on the nationality of ownership. While mindful of the limitations around nationality noted above, there is an even clearer difference here between London and the other cities. In New York and Toronto, less than $20 \%$ by value of our estimated investible stock was held by foreign-domiciled investors, with the hotel sector standing out as having the highest levels of foreign ownership over the period. In London, we estimate that over $50 \%$ of the investible stock by value by end-2017 was in foreign ownership, with substantial increases in the office and apartment sectors since the GFC. New York also saw a rise in foreign ownership over this period, but this was not shared by Toronto. In fact, results for Toronto are surprising, as they suggest that foreign ownership dropped markedly across all property types, but this might reflect stronger domestic flows with the rise of REITs, currency factors and muted price appreciation post-GFC as shown in Figure 1.

\section{INSERT TABLE IV HERE}

High levels of foreign ownership in London might be less surprising given the existing literature on this location, but the magnitude of the recent increase is marked. Nonetheless, it continues a long running trend in this market (Baum and Lizieri, 1999; Lizieri et al., 2000) and tallies with results of other studies for UK CRE. For instance, Mitchell (2014) noted that $56 \%$ of office stock by value in the City of London and $32 \%$ by value in the West End was foreign owned in 2013. Lizieri and Mekic (2018) provide results based on floorspace owned rather than value of real estate held for a sample of office buildings in the City of London. They identified that nearly two thirds of floorspace in their sample was foreign owned in 2014 compared to only one third in 2000. In terms of levels and changes, our figures for London offices and for London CRE overall are broadly in line with these earlier studies.

Whether these shifts in ownership affect levels of market activity is hard to judge over a short horizon because trading is required to bring about such changes. However, the greater share of institutional ownership in offices compared to other types of property, and in London versus other cities, together 
with the greater proportion of foreign ownership in London, are persistent characteristics that might impact on trading in those markets and submarkets. We measure turnover on an annual basis for each city and for each property type in those cities using the formula set out above, with metro level results shown in Figure 2 and results by property type in Table V. There is no clear relationship to ownership patterns when considering the average rate through time, but examination of turnover rates through the GFC period is revealing.

\section{INSERT FIGURE 2 HERE}

\section{INSERT TABLE V HERE}

Figure 2 indicates that the three cities had similar turnover rates in most years, with no city exhibiting consistently higher turnover, though the rates for New York are a little lower on average, as confirmed by Table V. The turnover rates in 2008 and 2009 are of specific interest since, while turnover drops in all of the cities, London's minimum of $7.6 \%$ is far above the $2.4 \%$ recorded for New York in 2009 and the 3.9\% recorded for Toronto that year. This finding is robust as to whether the whole city or just the central area is examined, and is repeated in figures for retail, office and industrial property. Away from London, offices appear to be no more heavily traded than any other property type. This comparison provides little evidence that institutional ownership increases trading activity, but it does suggest that the greater proportion of foreign ownership in London supported continued trading through adverse market conditions, improving price revelation and so contributing to the more rapid price adjustments observed in Figure 1.

Finally, the average office market turnover rates for New York and London can be compared to those found by Devaney et al. (2017) in their study of US cities and Devaney et al. (2019) in their international study. For New York MSA, Devaney et al. (2017) reported average annual turnover rates of $4.1 \%$ based 
on value traded and $8.9 \%$ based on floorspace traded over 2002-2015. For the same date range, our average for New York is higher at $11.8 \%$. However, their estimates for the stock value were based on combining floor area, rent per square foot and cap rate data, and are likely to be less reliable than the estimates generated here. They also noted that their New York result was anomalous when compared to other large US cities in their sample. In contrast, the estimate for London by Devaney et al. (2019) of $10.1 \%$ average turnover for 2007 to 2015 based on value traded is more consistent with our figure, but subject to the same caveats around their approach to estimation.

\section{Conclusion}

Reliable estimates of the value of commercial real estate markets matter to investors, researchers and policymakers. Estimates of the investible CRE stock, in particular, should inform portfolio allocations to and within the private real estate asset class, as well as facilitate measurement of market turnover and enhance understanding of market behaviour. Despite this, only broad country-level estimates for the value of CRE have been published with any regularity, while detailed, metropolitan-level estimates have been few and far between, reflecting the difficulty of obtaining reliable data. In the absence of a regular census of real estate values across all investor types, a diverse collection of approaches have been used to infer the value of either all CRE or investible CRE in the US and elsewhere. This includes the perpetual inventory approach as well as extrapolating figures from estimates for small samples of areas.

The method that we propose in this paper is based on using transaction data to build a picture of the investible CRE stock and its ownership through time. The key advantage is that transaction data are widely collected for CRE markets across the globe, including markets that lack alternative, census-style sources. We illustrate the method using RCA data for three relatively mature CRE investment markets, 
New York, London and Toronto, but the method is applicable to alternative datasets of transactions, whether these are proprietary or public in nature. Our application here is facilitated by the size of the RCA datasets and the availability of RCA CPPIs to index transaction prices through time in the markets we examine, albeit we acknowledge that the coverage of such proprietary datasets, even in respect of invested or investible real estate in specific locations, is not perfect.

The results of the study included estimates of the total value of investible CRE in each location, broken down by property type, and estimates of the proportion of stock held by different investor types. The results show that the ownership of CRE is very different in these three cities, with much larger shares of institutional ownership and foreign ownership in London, a much larger share of private investor ownership in New York, increasing ownership by listed real estate investors in New York and Toronto, and declining foreign ownership in Toronto. These results were compared to turnover rates. Although typical turnover rates did not vary much between the three cities, turnover dropped far less in London in the GFC years of 2008 and 2009 than in New York and Toronto. We suggest that it reflects the much more international and diverse ownership base, and there is scope for more research on this, perhaps drawing on the approaches to measurement of stock and turnover rates advocated here.

Our study has focused on the value of and turnover of the investible CRE market in each of the chosen cities. This has strong relevance to investment strategy and understanding investment markets, but it also reflects the difficulty of assessing total stock. Most easily accessible datasets of transactions are focused on CRE investment markets and a substantial component of the CRE stock may lie outside the ambit of the investment market. Some types of properties may be more likely to trade than others, though we anticipate that selection biases will reduce as the time span covered by a dataset increases. However, the portability of our method and the more widespread availability of the data it requires are important advantages when compared with alternative methods. This study illustrates how both the value and turnover of CRE investment markets can be monitored over time, and how changes in 
their ownership can be documented if the dataset used identifies the buyers and sellers of real estate assets.

\section{References}

Baum, A. and Lizieri, C. (1999), "Who Owns the City? Office Ownership and Overseas Investment in the City of London", Real Estate Finance, 1999, Vol. 16 No. 1, pp.87-100.

Chegut, A.M., Eichholtz P.M.A and Rodrigues, P.J.M. (2015), "Spatial Dependence in International Office Markets", Journal of Real Estate Finance and Economics, Vol. 51 No. 2, pp.317-350.

Collett, D., Lizieri, C. and Ward, C. (2003), "Timing and the Holding Periods of Institutional Real Estate", Real Estate Economics, Vol. 31 No. 2, pp.205-222.

Devaney, S., Livingstone, N., McAllister, P. and Nanda, A. (2019), “Capitalization Rates and Transaction Activity in International Office Markets: A Global Perspective", Global Finance Journal, Vol. 42, Forthcoming.

Devaney, S., McAllister, P. and Nanda, A. (2017), "Which Factors Determine Transaction Activity across U.S. Metropolitan Office Markets?", Journal of Portfolio Management, Vol. 43 No. 6, pp.90-104.

Devaney, S. and Scofield, D. (2017), “Do 'foreigners' pay more? The effects of investor type and nationality on office transaction prices in New York City", Journal of Property Research, Vol. 34 No. 1, pp.1-18.

DiPasquale, D. and Wheaton, W.C. (1992), "The markets for real estate assets and space: A conceptual framework", Journal of the American Real Estate and Urban Economics Association, Vol. 20 No. 2, pp.181-198.

Fisher, J.D. and Webb, R.B. (1992), "Current issues in the analysis of commercial real estate”, Journal of the American Real Estate and Urban Economics Association, Vol. 20 No. 2, pp.211-227. 
Fisher, J.D. and Young, M.S. (2000), "Institutional Property Tenure: Evidence from the NCREIF Database", Journal of Real Estate Portfolio Management, Vol. 6 No. 4, pp.327-338.

Fiorilla, P., Kapas, M. and Liang, Y. (2012), “An Institutional View of Global Real Estate Markets", Journal of Real Estate Portfolio Management, Vol. 18 No. 1, pp.123-133.

Florance, A.C., Miller, N.G., Peng, R. and Spivey, J. (2010), "Slicing, Dicing and Scoping the Size of the U.S. Commercial Real Estate Market", Journal of Real Estate Portfolio Management, Vol. 16 No. 2, pp.101-118.

Freybote, J. and Seagraves, P.A. (2017), “Heterogeneous Investor Sentiment and Institutional Real Estate Investments", Real Estate Economics, Vol. 45 No. 1, pp.154-176.

Geltner, D., MacGregor, B.D. and Schwann, G.M. (2003), “Appraisal Smoothing and Price Discovery in Real Estate Markets", Urban Studies, Vol. 40 No. 5/6, pp.1047-1064.

Geltner, D. and Pollakowski, H. (2007), A Set of Indexes for Trading Commercial Real Estate Based on the Real Capital Analytics Transaction Prices Database, MIT Center for Real Estate, Cambridge, MA. Hartzell, D., Pittman, R. and Downs, D. (1994), “An updated look at the size of the US real estate market portfolio", Journal of Real Estate Research, Vol. 9 No. 2, pp.197-212.

Higgins, D. (2005), "Modelling the Australian Property Investment Universe: A Preliminary Study", Pacific Rim Property Research Journal, Vol. 11 No. 3, pp.268-281.

Higgins, D. (2013), Australian Commercial Property Investment Market: Styles, Performance and Funding, RMIT University / Australian Centre for Financial Studies.

IPF (2004), Liquidity in Commercial Property Markets, London: Investment Property Forum.

Key, T. and Law, V. (2005), The Size and Structure of the UK Property Market, London: Investment Property Forum.

Key, T., Moss, A., Chaplin, R. and Law, V. (2019), The Size and Structure of the UK Property Market: End-2018 Update, London: Investment Property Forum.

Liang, Y. and McIntosh, W. (1999), Global Commercial Real Estate, New Jersey: Prudential Real Estate Investors. 
Lizieri, C., Baum A. and Scott, P. (2000), “Ownership, Occupation and Risk: A View of the City of London Office Market", Urban Studies, Vol. 37 No. 7, pp.1109-1129.

Lizieri, C. and Mekic, D. (2018), "Real estate and global capital networks: drilling into the City of London", Hoyler, M., Parnreiter, C. and Watson, A. (Eds.), Global City Makers: Economic Actors and Practices in the World City Network, Edward Elgar, Cheltenham, pp.60-82.

Mahoney, J., Malpezzi, S. and Shilling, J.D. (2000), “Implications of Income Property Stock Data for Real Estate Investment Portfolio Location", Real Estate Finance, Vol. 16 No. 4, pp.53-66.

Malpezzi, S. and Shilling, J.D. (2000), "Institutional Investors Tilt Their Real Estate Holdings Toward Quality, Too", Journal of Real Estate Finance and Economics, Vol. 21 No. 2, pp.113-140.

Malpezzi, S., Shilling, J.D. and Yang, Y.J. (2001), "The Stock of Private Real Estate Capital in U.S. Metropolitan Areas", Journal of Real Estate Research, Vol. 22 No. 3, pp.243-270.

McAllister, P. and Nanda, A. (2015), “Does Foreign Investment Affect US Office Real Estate Prices?", The Journal of Portfolio Management, Vol. 41 No. 6, pp.38-47.

Miles, M.E. (1990), "Estimating the Size of the Real Estate Market in the US", Real Estate Review, Vol. 20 No. 2, pp.69-77.

Miles, M., Pittman, R., Hoesli, M., Bhatnager, P. and Guilkey, D. (1991), “A Detailed Look at America's Real Estate Wealth", Journal of Property Management, Vol. 56 No. 4, pp.45-51.

Miles, M., Roberts, J., Machi, D. and Hopkins, R. (1994), "Sizing the investment markets: A look at the major components of public and private markets", Real Estate Finance, Vol. 11 No. 1, pp.39-50.

Miles, M. and Tolleson, N. (1997), "A revised look at how real estate compares with other major components of the domestic investment universe", Real Estate Finance, Vol. 14 No. 1, pp.11-21.

Mitchell, P. (2014), The Size and Structure of the UK Property Market 2013: A Decade of Change, Investment Property Forum, London.

Newell, G., Kupke, V. and McGreal, S. (2013), "The Significance of Capital Flows into the Australian Commercial Property Markets", Pacific Rim Property Research Journal, Vol. 19 No. 1, pp.3-15. 
Rogers, T. and Blake, N. (2013), The Role of Commercial Property in the UK Economy, Investment Property Forum, London.

Scofield, D. and Devaney, S. (2017), "What Sells in a Crisis? Determinants of Transaction Frequency over a Cycle and Through a Crash", Journal of Property Investment and Finance, Vol. 35 No. 6, pp.619-637.

Silver, M. and Graf, B. (2014), Commercial Property Price Indexes: Problems of Sparse Data, Spatial Spillovers, and Weighting, IMF Working Paper WP/14/72, International Monetary Fund.

Teuben, B. and Bothra, H. (2019), Real Estate Market Size 2018, MSCl.

Young, A. and Musgrave, J.C. (1980), "Estimation of Capital Stock in the United States", Usher, D. (Ed.), The Measurement of Capital, University of Chicago Press, Chicago, pp.23-82.

Young, M.S. (2005), "Making sense of the NCREIF Property Index: a new formulation revisited", Journal of Real Estate Portfolio Management, Vol. 11 No. 3, pp.211-223.

\section{Endnotes}

[1] In relation to lot size, low value assets do not facilitate the efficient placement of capital by professional investors and can involve disproportionate management costs.

[2] Estimates were attempted of the institutional grade office market as well by extrapolating detailed data from Philadelphia and Seattle office markets.

[3] Note that Higgins $(2005,2013)$ has undertaken similar exercises to estimate the total value of CRE and the value of the CRE investment market in Australia.

[4] As it happens, we find a large number of transactions in our London and Toronto datasets that are below the $\$ 10 \mathrm{~m}$ threshold. 1,545 of the 3,053 transactions in our Toronto sample relate to assets sold for less than $\$ 10 \mathrm{~m}$ USD and the same is true for 1,317 of the 7,847 transactions in our London sample. 
[5] We remove transactions of development land from the samples. This is because it is difficult to speculate as to when it will be developed and what will be built. Once a newly built asset is traded, value can be estimated, and ownership attributed, back to the year of construction as per the method described below.

[6] RCA CPPIs for London CRE run from Q4 2002 rather than the start of 2001. For this study, we extended the CPPIs back to Q1 2001 using changes in average price per square foot for properties sold in each quarter in the submarket concerned.

\section{Acknowledgements}

We thank Real Capital Analytics for the provision of data required to undertake this study. We thank the anonymous reviewers and the participants at both the 2018 REALPAC/Ryerson symposium and the 2019 American Real Estate Society meeting for comments and feedback. 
Table I: Summary of transactions and price growth by market

\begin{tabular}{l|rrr}
\hline & New York & London & Toronto \\
\hline Transaction sample start & $2001 q 1$ & $2001 q 1$ & $2007 q 1$ \\
Number of transactions & 32,390 & 7,847 & 3,053 \\
Transaction volume USD bn & 696.9 & 506.8 & 66.5 \\
Average deal size USD m & 21.5 & 64.6 & 21.8 \\
Price growth end-06 to end-17 & $88 \%$ & $55 \%$ & $69 \%$ \\
Quarterly average growth rate & $1.5 \%$ & $1.1 \%$ & $1.2 \%$ \\
Standard deviation in growth rates & $3.2 \%$ & $3.8 \%$ & $2.2 \%$ \\
Peak to trough change in GFC & $-24 \%$ & $-37 \%$ & $-13 \%$ \\
\hline
\end{tabular}

Note: Price growth statistics based on the published metro-level RCA Commercial Property Price Index covering all property types. The number and volume of transactions is based on the specific sample provided to the authors. 
Table II: Estimates of investible CRE stock value in local currency and in US dollar terms

\begin{tabular}{|c|c|c|c|c|c|c|}
\hline & $\begin{array}{c}\text { Apartment } \\
\text { LOC }\end{array}$ & $\begin{array}{l}\text { Office } \\
\text { LOC }\end{array}$ & $\begin{array}{l}\text { Total } \\
\text { LOC }\end{array}$ & $\begin{array}{l}\text { Apartment } \\
\text { USD }\end{array}$ & $\begin{array}{l}\text { Office } \\
\text { USD }\end{array}$ & $\begin{array}{l}\text { Total } \\
\text { USD }\end{array}$ \\
\hline \multicolumn{7}{|l|}{ New York } \\
\hline End-2001 bn & 44 & 85 & 187 & 44 & 85 & 187 \\
\hline End-2006 bn & 88 & 164 & 363 & 88 & 164 & 363 \\
\hline End-2011 bn & 101 & 164 & 374 & 101 & 164 & 374 \\
\hline End-2017 bn & 223 & 270 & 700 & 223 & 270 & 700 \\
\hline \multicolumn{7}{|l|}{ London } \\
\hline End-2001 bn & 2 & 62 & 87 & 3 & 91 & 127 \\
\hline End-2006 bn & 4 & 105 & 150 & 8 & 205 & 294 \\
\hline End-2011 bn & 4 & 104 & 146 & 7 & 161 & 226 \\
\hline End-2017 bn & 13 & 185 & 272 & 18 & 250 & 367 \\
\hline \multicolumn{7}{|l|}{ Toronto } \\
\hline End-2006 bn & 6 & 17 & 44 & 5 & 15 & 38 \\
\hline End-2011 bn & 7 & 21 & 51 & 7 & 20 & 50 \\
\hline End-2017 bn & 12 & 32 & 82 & 10 & 26 & 66 \\
\hline
\end{tabular}

Note: Currency conversion based on year-end spot rates obtained from Bank of England database [accessed in July 2020 at www.bankofengland.co.uk/boeapps/database/default.asp]. 
Table III: Proportion of stock by value owned by selected investor types

\begin{tabular}{|c|c|c|c|c|c|c|}
\hline & \multicolumn{3}{|c|}{ Office stock } & \multicolumn{3}{|c|}{ Total CRE } \\
\hline & Institution & Private & Public & Institution & Private & Public/listed \\
\hline \multicolumn{7}{|l|}{ New York } \\
\hline End-2001 \% & 35.2 & 39.9 & 8.2 & 22.2 & 53.0 & 8.3 \\
\hline End-2006 \% & 30.4 & 44.4 & 13.1 & 22.2 & 54.2 & 11.8 \\
\hline End-2011 \% & 33.8 & 38.9 & 15.7 & 25.2 & 50.3 & 13.9 \\
\hline End-2017 \% & 34.9 & 41.0 & 14.6 & 24.8 & 53.1 & 14.1 \\
\hline \multicolumn{7}{|l|}{ London } \\
\hline End-2001 \% & 48.7 & 20.9 & 15.8 & 46.7 & 21.9 & 16.2 \\
\hline End-2006 \% & 53.3 & 22.7 & 13.1 & 50.0 & 25.3 & 13.4 \\
\hline End-2011 \% & 55.5 & 23.1 & 10.7 & 50.4 & 27.0 & 11.3 \\
\hline End-2017 \% & 52.6 & 26.0 & 12.0 & 50.2 & 28.4 & 11.7 \\
\hline \multicolumn{7}{|l|}{ Toronto } \\
\hline End-2006 \% & 48.4 & 18.0 & 9.5 & 31.4 & 32.7 & 10.3 \\
\hline End-2011 \% & 49.7 & 12.9 & 19.2 & 34.1 & 28.9 & 16.3 \\
\hline End-2017\% & 47.5 & 20.2 & 24.7 & 33.4 & 30.9 & 23.8 \\
\hline
\end{tabular}

Note: classification is based on RCA's attribution of owner type. In the case of assets owned by joint ventures, where partners are in different ownership categories, the value estimate has been split in equal proportion between the relevant categories. 
Table IV: Proportion of stock in foreign investor ownership - by city and sector

\begin{tabular}{|c|c|c|c|c|c|c|}
\hline & Apartment & Hotel & Industrial & Office & Retail & Total \\
\hline \multicolumn{7}{|l|}{ New York } \\
\hline End-2001 \% & 0.8 & 11.9 & 2.3 & 14.4 & 4.6 & 8.3 \\
\hline End-2006 \% & 1.6 & 14.8 & 2.3 & 13.2 & 4.9 & 8.2 \\
\hline End-2011 \% & 2.5 & 15.6 & 1.8 & 16.0 & 7.1 & 10.0 \\
\hline End-2017\% & 5.5 & 32.4 & 4.4 & 21.1 & 9.0 & 13.9 \\
\hline \multicolumn{7}{|l|}{ London } \\
\hline End-2001 \% & 14.8 & 38.3 & 19.8 & 30.2 & 19.7 & 28.4 \\
\hline End-2006 \% & 23.4 & 40.2 & 16.0 & 36.3 & 25.4 & 33.6 \\
\hline End-2011 \% & 26.9 & 45.7 & 19.0 & 47.6 & 32.9 & 43.5 \\
\hline End-2017\% & 40.4 & 56.7 & 24.0 & 57.9 & 42.4 & 53.3 \\
\hline \multicolumn{7}{|l|}{ Toronto } \\
\hline End-2006 \% & 10.2 & 36.0 & 18.7 & 16.3 & 9.6 & 15.5 \\
\hline End-2011 \% & 2.3 & 31.1 & 14.7 & 13.3 & 7.9 & 11.9 \\
\hline End-2017\% & 8.1 & 22.1 & 7.2 & 5.7 & 3.4 & 6.9 \\
\hline
\end{tabular}

Note: classification is based on RCA's attribution of owner type. In the case of assets owned by joint ventures, where partners are in different ownership categories, the value estimate has been split in equal proportion between the relevant categories. 
Table V: Average and range in turnover rates - by city and sector

\begin{tabular}{|c|c|c|c|c|c|c|}
\hline & Apartment & Hotel & Industrial & Office & Retail & Total \\
\hline \multicolumn{7}{|c|}{ New York 2002-17 } \\
\hline Average \% & 9.6 & 10.2 & 8.2 & 11.5 & 8.8 & 10.2 \\
\hline St. Deviation & 4.6 & 5.8 & 3.2 & 4.2 & 4.3 & 3.7 \\
\hline Minimum \% & 2.6 & 2.0 & 2.7 & 1.9 & 3.3 & 2.4 \\
\hline Maximum \% & 18.3 & 18.6 & 13.5 & 20.9 & 17.0 & 15.8 \\
\hline \multicolumn{7}{|c|}{ London 2002-17 } \\
\hline Average \% & 12.5 & 11.6 & 7.9 & 12.8 & 10.2 & 12.1 \\
\hline St. Deviation & 9.0 & 5.6 & 2.6 & 3.7 & 3.4 & 3.1 \\
\hline Minimum \% & 2.6 & 2.9 & 5.1 & 7.9 & 5.4 & 7.6 \\
\hline Maximum \% & 32.5 & 21.2 & 13.0 & 18.6 & 16.4 & 16.4 \\
\hline \multicolumn{7}{|c|}{ Toronto 2007-17 } \\
\hline Average \% & 10.6 & 12.7 & 11.0 & 12.2 & 11.2 & 11.6 \\
\hline St. Deviation & 3.7 & 6.6 & 4.1 & 4.0 & 5.6 & 3.3 \\
\hline Minimum \% & 4.1 & 3.7 & 3.6 & 4.3 & 2.8 & 3.9 \\
\hline Maximum \% & 15.9 & 21.2 & 15.9 & 19.6 & 18.1 & 15.2 \\
\hline
\end{tabular}

Note: Turnover rates measured for each year by taking the volume of transactions that year and dividing this by the average of the year end and prior year end stock values as per discussion in text. 
Figure 1: RCA CPPI price trends in local currency terms by market

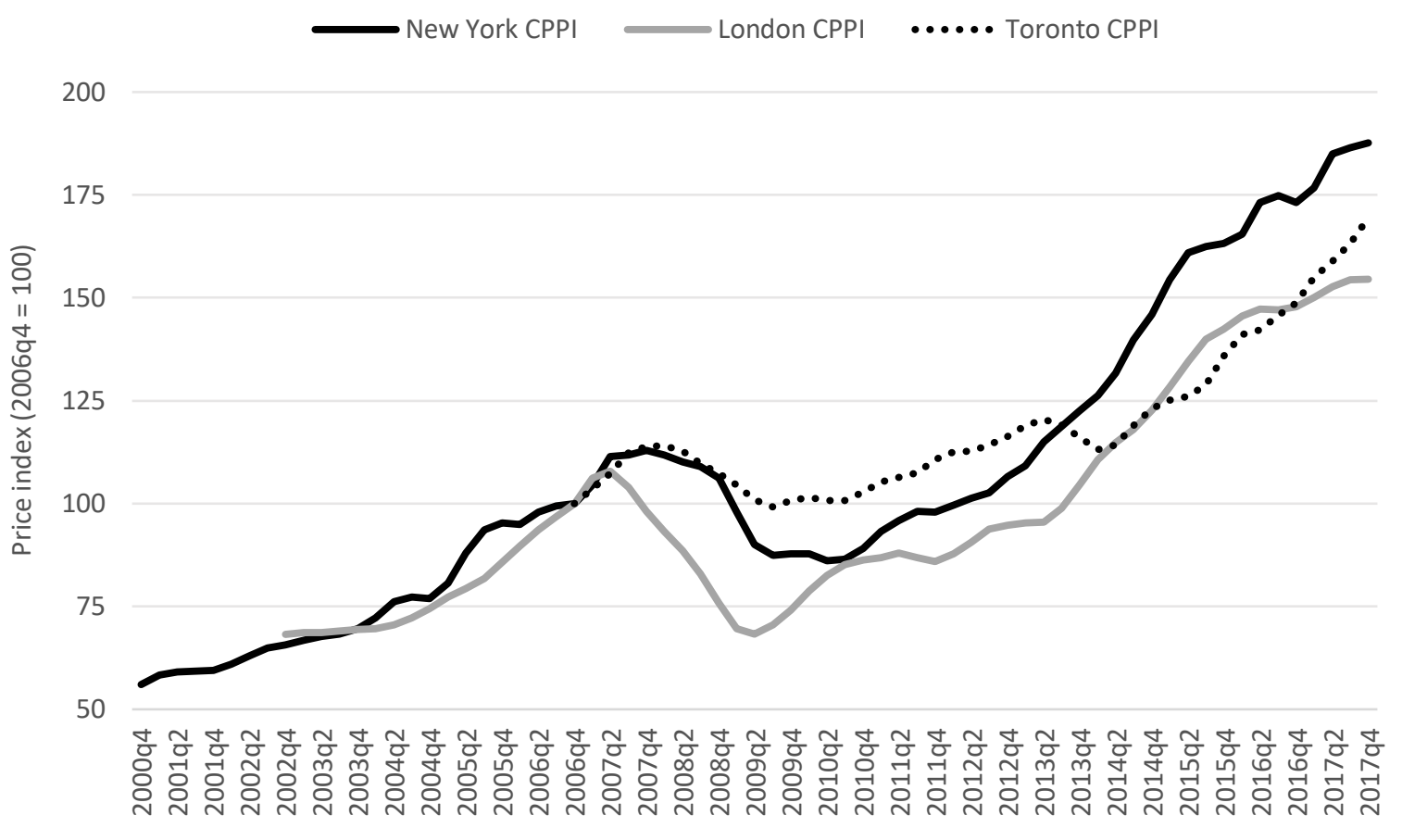

Note: Price trends based on the published metro-level RCA Commercial Property Price Index covering all property types. The CPPI for London begins at 2002q4, but has been extended back by the authors for the stock estimates (see main text). 
Figure 2: Market turnover rates by metro - 2002-17

- New York London 㯺 Toronto

$18 \%$

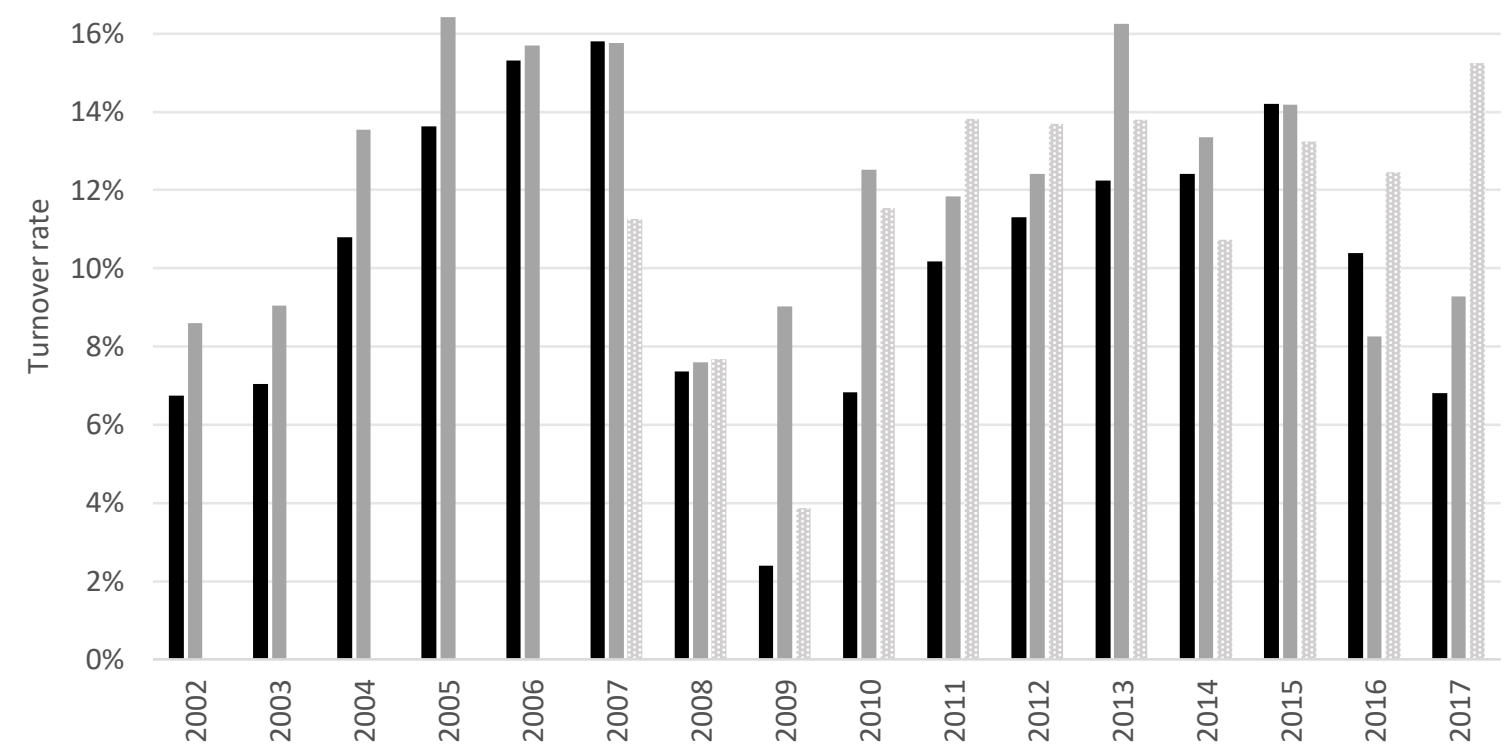

Note: Turnover rates measured for each year by taking the volume of transactions that year and dividing this by the average of the year end and prior year end stock values as per discussion in text. 